\title{
Intramolecular Hetero-Diels-Alder Reaction of N-Arylimines. Applications to the Synthesis of Octahydroacridine Derivatives
}

\author{
Sabine Laschat* and Jürgen Lauterwein \\ Organisch-Chemisches Institut der Universität Münster, Corrensstr. 44, W-4400 Münster, FRG
}

Received November 20, 1992

\begin{abstract}
A new intramolecular Lewis acid catalyzed hetero-Diels-Alder reaction of $\mathrm{N}$-arylimines 5 with nonactivated olefins tethered to the 2-azadiene system was developed in order to prepare 1,2,3,4,$4 a, 9,9 a, 10$-octahydroacridine derivatives 6 . Both reactivity and cis/trans selectivity of 6 were mainly dependent on the substitution pattern in the 3-position of the cyclization precursor 5 . The type of Lewis acid plays only a minor role in determination of the cis/trans ratio. The synthetic utility of this new cyclization was increased by performing it as a one-pot reaction $(3+4 \rightarrow 6)$. Both absolute configuration and preferred conformation were assigned by detailed NMR studies.
\end{abstract}

\section{Introduction}

The Lewis acid-catalyzed hetero-Diels-Alder reaction of $\mathrm{N}$-arylimines, which were used as 2-azadienes, was studied almost 30 years by Povarov and co-workers. ${ }^{1}$ However, until now only those reactions with electronrich dienophiles such as dihydrofurans, ${ }^{2}$ enol ethers, $, 1,3$ enamines, ${ }^{4}$ and ketenes ${ }^{5}$ were investigated. In a more recent approach by Grieco ${ }^{6}$ and Mellor, ${ }^{7} \mathrm{~N}$-arylimines derived from formaldehyde reacted with electron-rich dienophiles to give polycylic ring systems. In this article we report a new intramolecular type of hetero-Diels-Alder reaction of $\mathrm{N}$-arylimines 1 with nonactivated olefins tethered to the diene system, which results in the formation of $1,2,3,4,4 a, 9,9 a, 10$-octahydroacridines 2 (eq 1), a class of pharmacological interesting compounds. . $^{8-10}$

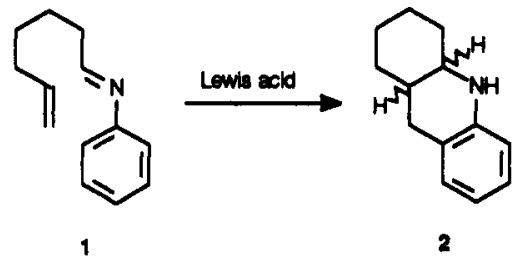

Several syntheses of the octahydroacridine skeleton have previously been reported, e.g., such as catalytic hydro-

(1) (a) Povarov, L. S.; Mikhailov, B. M. Izv. Akad. Nauk. SSSR Otd. Khim. Nauk. 1963, 955-956. (b) For a review see: Povarov, L. S. Russ. Chem. Rev. 1967, 36, 656-670.

(2) Lucchini, V.; Prato, M.; Scorrano, G.; Stivanello, M.; Valle, G. J. Chem. Soc., Perkin Trans. 2, 1992, 259-266.

(3) (a) Elslager, E. F.; Worth, E. F. J. Heterocycl. Chem. 1969, 6, $597-$ 598. (b) Perricone, S. C.; Elslager, E. F.; Worth, D. F. J. Heterocycl. Chem. 1970, 7, 135-138. (c) Trifonov, L. S.; Orohovats, A. S. Heterocycles 1984, 22, 355-364. (d) Kametani, T.; Takeda, H.; Suzuki, Y.; Honda, T. Synth. Commun. 1985, 15, 499-505. (e) Ojima, I.; Inaba, S. I.; Yoshida, K. Tetrahedron Lett. 1977, 3643-3646.

(4) (a) Tomoda, S.; Takeuchi, Y.; Nomura, Y. Tetrahedron Lett. 1969, 3549-3552. (b) Nomura, Y.;Kimura, M.; Takeuchi, Y.; Tomoda, S. Chem. Lett. 1978, 267-270. (c) Goasdone, C.; Gaudemar, M. Tetrahedron Lett. 1985, 1015-1018.

(5) (a) Moore, H. W.; Hughes, G.; Srinivasachar, K.; Fernandez, M.; Nguyen, N. V.; Schoon, D.; Tranne, A. J. Org. Chem. 1985, 50, 4231-4238. (b) Aben, R. W. M.; Smit, R.; Scheeren, J. W. J. Org. Chem. 1987, 52, 365-370.

(6) Grieco, P. A.; Bahsas, A. Tetrahedron Lett. 1988, 5855-5858.

(7) Mellor, J. M.; Merriman, G. D.; Riviere, P. Tetrahedron Lett. 1991 , $7103-7106$.

(8) Ermolaeva, V.G.; Yashunskii, V.G.; Polezhaeva, A. I.; Mashkovskii, M. D. Khim. Farm. Zh. 1968, 2, 20-23; Chem. Abstr. 1968, 69, 106517p. (9) Canas-Rodriguez, A.; Canas, R. G.; Mateo-Bernardo, A. An. Quim., Ser. C. 1987, 83, 24-27; Chem. Abstr. 1988, 108, 112191t.

(10) (a) Lafargue, P. Moriniere, J. L. Pont, P. Mennier, J. C. R. Acad. Sci., Ser. C 1970, 270, 1186-1188. (b) Schultz, H.; Ebel, S.; Fitz, H. Arzneim. Forsch. 1985, 35, 1015-1024. genation of acridine, ${ }^{11}$ intramolecular Beckmann rearrangement of oxime sulfonates, ${ }^{12}$ amino-Claisen rearrangement of geranyl aniline, ${ }^{13}$ condensation of aniline with anthranilic acid followed by chlorination and reduction, ${ }^{9}$ and acid-catalyzed condensation of aniline with isophorone. ${ }^{14}$ However, the above-mentioned syntheses are only of limited synthetic value, especially because of the lack of stereochemical control of the ring fusion. An intramolecular Diels-Alder reaction of 1 should give rise to the desired ring system 2 in a stereocontrolled manner. ${ }^{15}$

\section{Results and Discussion}

As shown in Scheme I and Table I, treatment of $\mathrm{N}$-arylimines 5 in $\mathrm{CH}_{2} \mathrm{Cl}_{2}$ with catalytic amounts of $\mathrm{SnCl}_{4}$ (0.1 equiv) for several hours at $-78^{\circ} \mathrm{C}(\operatorname{method} \mathrm{A})$ followed by basic hydrolysis resulted in the formation of octahy. droacridines 6 in high yields. In the case of the 3-dimethylsubstituted $\mathrm{N}$-arylimines $\mathbf{5 a}, \mathbf{b}$ the corresponding cyclization products were formed with extremely high trans selectivity (trans/cis $=99: 1$ ). We found that the cyclization also can be carried out as a one-pot reaction by successive addition of the Lewis acid and the aldehyde 3 to a precooled solution $\left(-78^{\circ} \mathrm{C}\right)$ of the amine 4 in $\mathrm{CH}_{2} \mathrm{Cl}_{2}$ (method B). ${ }^{16}$ As shown in Table I the yields and cis/trans ratios of the one-pot reaction are quite similar to the cyclization of isolated imines 5. Concerning the stereochemistry of the ring fusion, the substituents $R^{1}$ and $R^{2}$ in the 3-position of 5 have a significant influence on the cis/trans ratio.

(11) (a) Sakanishi, K.; Mochida, I.; Okazaki, H.; Soeda, M. Chem. Lett. 1990, 319-322 and references cited therein. (b) Nagai, M.; Masunaga, T. Fuel 1988, 67, 771-774. (c) Ermolaeva, V. G.; Kostyuchenko, N. P.; Yashunskii, V. G.; Sheinker, Y.N. Khim. Farm. Zh. 1969, 3, 19-23; Chem. Abstr. 1969, 71, 124190x. (d) Nagai, M. Bull. Chem. Soc. Jpn. 1991, 64, 330-332. (e) Sakanishi, K.; Ohira, M.; Mochida, I.; Okazaki, H.; Soeda, M. J. Chem. Soc., Perkin Trans, 2 1988, 1769-1773. (f) Mochida, I.; Sakanishi, K.; Korai, Y.; Fujitsu, H. Chem. Lett. 1985, 909-912.

(12) Sakane, S.; Matsumura, Y.; Yamamura, Y.; Ishida, Y.; Maruoka, K.; Yamamoto, H. J. Am. Chem. Soc. 1983, 105, 672-674.

(13) Tanaka, J.; Takabe, K.; Taniguchi, K.; Katagiri, T. Nippon Kagaku Kaishi 1981, 1043-1045; Chem. Abstr. 1981, 95, 219818t

(14) Layer, R. W.; Westfahl, J. C. J. Org. Chem. 1979, 44, 1146-1149.

(15) For recently published stereocontrolled synthesis of the basic tetrahydroquinoline system by Diels-Alder reaction of azarylylenes with electron-poor dienophiles, which is, however, limited to a specific substitution pattern of the aromatic ring and the dienophile, see: Wojciechowski, K. Synlett 1991, 571-572.

(16) In order to obtain a clean one-pot reaction, the aldehyde 3 was added very slowly (over $1 \mathrm{~h}$ ) to the reaction mixture; otherwise, a substantial amount of 3-substituted 6-(2-isopropenyl)cyclohexanol, i.e, the product of an intramolecular Lewis acid-catalyzed ene reaction of 3 , was isolated. 
Scheme I<smiles>[2H][13CH]([14CH3])CCC=O</smiles>

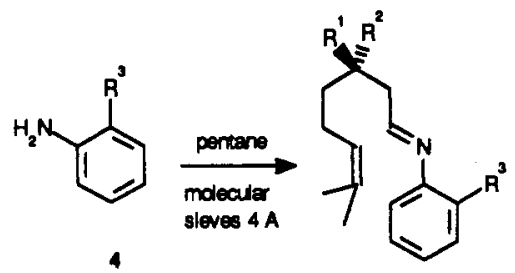

3

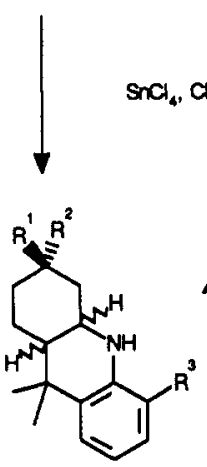

Baf

6at

Table I. Preparation of Octahydroacridines $6^{a, b}$

\begin{tabular}{|c|c|c|c|c|c|c|c|c|c|}
\hline \multirow[b]{2}{*}{ imine } & \multirow[b]{2}{*}{$\mathbf{R}^{1}$} & \multirow[b]{2}{*}{$\mathrm{R}^{2}$} & \multirow[b]{2}{*}{$\mathbf{R}^{3}$} & \multirow[b]{2}{*}{ method } & \multirow{2}{*}{$\begin{array}{c}\text { reactn } \\
\text { time } \\
\text { (h) }\end{array}$} & \multirow[b]{2}{*}{ product } & \multirow{2}{*}{$\begin{array}{c}\text { yield } \\
(\%)\end{array}$} & \multicolumn{2}{|c|}{$\begin{array}{c}\text { products } \\
6(\%)\end{array}$} \\
\hline & & & & & & & & $\overline{\text { cis }}$ & trans \\
\hline $\begin{array}{l}\mathbf{5 a} \\
\mathbf{5 a} \\
\mathbf{5 b} \\
\mathbf{5 b} \\
\mathbf{5 c} \\
\mathbf{5 d} \\
\mathbf{5 e} \\
\mathbf{5 e} \\
\mathbf{5 f} \\
\mathbf{5 f}\end{array}$ & $\begin{array}{l}\mathrm{Me} \\
\mathrm{Me} \\
\mathrm{Me} \\
\mathrm{Me} \\
\mathrm{Me} \\
\mathrm{Me} \\
\mathrm{H} \\
\mathrm{H} \\
\mathrm{H} \\
\mathrm{H}\end{array}$ & $\begin{array}{l}\mathrm{Me} \\
\mathrm{Me} \\
\mathrm{Me} \\
\mathrm{Me} \\
\mathrm{H} \\
\mathrm{H} \\
\mathrm{H} \\
\mathrm{H} \\
\mathrm{H} \\
\mathrm{H}\end{array}$ & $\begin{array}{l}\mathrm{Me} \\
\mathrm{Me} \\
\mathrm{H} \\
\mathrm{H} \\
\mathrm{Me} \\
\mathrm{H} \\
\mathrm{Me} \\
\mathrm{Me} \\
\mathrm{H} \\
\mathrm{H}\end{array}$ & $\begin{array}{l}\text { A } \\
\text { B } \\
\text { A } \\
\text { B } \\
\text { B } \\
\text { B } \\
\text { A } \\
\text { B } \\
\text { A } \\
\text { B }\end{array}$ & $\begin{array}{r}24 \\
27 \\
21 \\
27 \\
46 \\
46 \\
109 \\
19 \\
109 \\
12\end{array}$ & $\begin{array}{l}\mathbf{6 a} \\
\mathbf{6 a} \\
\mathbf{6 b} \\
\mathbf{6 b} \\
\mathbf{6 c} \\
\mathbf{6 d} \\
\mathbf{6 e} \\
\mathbf{6 e} \\
\mathbf{6 f} \\
\mathbf{6 f}\end{array}$ & $\begin{array}{l}91 \\
86 \\
86 \\
72 \\
84 \\
84 \\
35 \\
64\end{array}$ & $\begin{array}{r}1 \\
1 \\
1 \\
0 \\
42 \\
31 \\
64 \\
57 \\
39 \\
41\end{array}$ & $\begin{array}{c}99 \\
99 \\
99 \\
100 \\
56^{c} \\
67^{d} \\
36 \\
43 \\
60 \\
57\end{array}$ \\
\hline
\end{tabular}

a Cyclization of isolated imines $5(\operatorname{method} A)$ or one-pot reaction of aldehyde 3 and amine 4 (method B) with 0.1 equiv of $\mathrm{SnCl}_{4}$ in $\mathrm{CH}_{2} \mathrm{Cl}_{2}$ at $-78^{\circ} \mathrm{C} .{ }^{b} \mathrm{Cis} /$ trans ratios were determined by capillary GC. ${ }^{c}$ Two additional diastereomers $(0.3 \%$ and $1.5 \%$, relative to cis/ trans-6c) were also detected. ${ }^{d}$ Two additional diastereomers $(0.3 \%$ and $1.7 \%$, relative to cis/trans-6d) were also detected.

Steric bulk at C-3 favors formation of the trans product. While the gem-dimethyl-substituted derivative 5a yielded almost exclusively the trans product $6 \mathrm{a}$ ( $99 \%$ via method $B)$, the amount of the cis isomer increased in the case of $6 c(42 \%$, method B) and $6 e(57 \%$, method B). In the case of imines $\mathbf{5 c}, \mathbf{d}$, which were derived from optically pure $(R)$-citronellal, two minor cyclization products were also detected; however, their total amount was usually below $5 \%$. The similarity of the GC-mass spectra of these minor products as compared to those of the major products suggests that they are diastereomers of cis/trans-6c,d.

We studied the cyclization using different solvents and Lewis acids with $\mathrm{N}$-arylimines $5 \mathrm{a}, \mathrm{c}$ as test substrates. Table II shows that the cyclization reaction can be done both in nonpolar and polar, noncoordinating solvents. Donor solvents like ether or THF which decrease the acidity of the Lewis acid by complexation are not useful. While the arylimine 5a shows almost the same reactivity and selectivity (entries 1,2 , and 4) in either $\mathrm{CH}_{2} \mathrm{Cl}_{2}$, toluene, or pentane, the reactivity of $5 \mathrm{c}$ decreases in the order toluene $>\mathrm{CH}_{2} \mathrm{Cl}_{2}>$ pentane (entries 9,10 , and 12), whereas the selectivity order for $5 \mathrm{c}$ is toluene $>$ pentane $>\mathrm{CH}_{2} \mathrm{Cl}_{2}$.

The formation of the octahydroacridine 6 can be catalyzed by a broad range of Lewis or Brönsted acids. As
Table II. Cyclization of N-Arylimines 5a $\left(\mathbf{R}^{1}=\mathbf{R}^{2}=\mathbf{R}^{3}=\right.$ Me) and $5 c\left(R^{1}=R^{3}=M e, R^{2}=H\right)$ With 0.1 equiv of $\mathrm{SnCl}_{4}$ in Different Solvents*

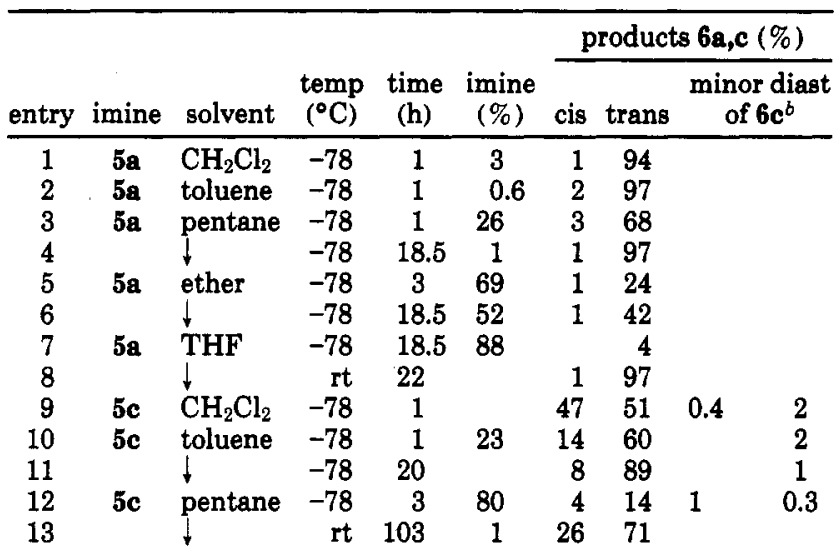

a Yields of the products and recovered imine were determined by capillary GLC using $n$-octadecane as internal standard. ${ }^{b}$ The configuration of these two minor diastereomers was not determined.

Table III. Cyclization of N-Arylimines 5a,c with Different Lewis Acids (0.1 equiv) in $\mathrm{CH}_{2} \mathrm{Cl}_{2}{ }^{\mathrm{a}}$

\begin{tabular}{|c|c|c|c|c|c|c|c|c|}
\hline \multirow[b]{2}{*}{ imine } & \multirow[b]{2}{*}{$\begin{array}{l}\text { Lewis } \\
\text { acid }\end{array}$} & \multirow[b]{2}{*}{$\begin{array}{c}\text { temp } \\
\left({ }^{\circ} \mathrm{C}\right)\end{array}$} & \multirow[b]{2}{*}{$\begin{array}{l}\text { time } \\
\text { (h) }\end{array}$} & \multirow[b]{2}{*}{$\underset{(\%)}{\operatorname{imine}}$} & \multicolumn{4}{|c|}{ products $6 \mathrm{a}, \mathrm{c}(\%)$} \\
\hline & & & & & cis & trans & & $\begin{array}{l}\text { diast } \\
\mathrm{c}^{b}\end{array}$ \\
\hline $\mathbf{5 a}$ & $\mathrm{ZnCl}_{2}$ & rt & 14 & 5 & 3 & 91 & & \\
\hline $5 \mathbf{a}$ & $\mathrm{T}$ & -78 & 17 & 1 & 1 & 98 & & \\
\hline $\mathbf{5 a}$ & $\mathrm{FeCl}_{3}$ & -78 & 1 & 1 & 3 & 94 & & \\
\hline $\mathbf{5 a}$ & $\mathrm{BF}_{3} \cdot \mathrm{OEt}_{2}$ & -78 & 15 & 1 & 1 & 98 & & \\
\hline $\mathbf{5 a}$ & $\mathrm{AlCl}_{3}$ & rt & 8.5 & & 1 & 97 & & \\
\hline $\mathbf{5 a}$ & $\mathrm{Et}_{2} \mathrm{AlCl}$ & -78 & 15 & 5 & 1 & 93 & & \\
\hline $\mathbf{5 a}$ & EtAlCl$_{2}$ & -78 & 15 & 0.2 & 1 & 96 & & \\
\hline $\mathbf{5 a}$ & $\mathrm{CF}_{3} \mathrm{CO}_{2} \mathrm{H}$ & -78 & 25 & 2 & 0.4 & 97 & & \\
\hline $\mathbf{5 a}$ & $p-\mathrm{TsOH}$ & $\mathrm{rt}$ & 8.5 & & 1 & 98 & & \\
\hline $\mathbf{5 a}$ & PPA & $\mathrm{rt}$ & 20.5 & & 3 & 96 & & \\
\hline 5c & $\mathrm{ZnCl}_{2}$ & $\mathrm{rt}$ & 14 & 1 & 39 & 58 & & 2 \\
\hline sc & $\mathrm{TiCl}_{4}$ & -78 & 17 & 31 & 15 & 52 & & 2 \\
\hline 5c & $\mathrm{FeCl}_{3}$ & -78 & 1 & 2 & 47 & 49 & & 2 \\
\hline $5 c$ & $\mathrm{BF}_{3} \cdot \mathrm{OEt}_{2}$ & -78 & 1 & 1 & 22 & 73 & 0.3 & 3 \\
\hline 5c & $\mathrm{AlCl}_{3}$ & -78 & 18 & 0.2 & 39 & 58 & & 1 \\
\hline 5 & & -78 & 18 & & 45 & 53 & & 0.1 \\
\hline 5 & Et. & -78 & 18 & & 43 & 54 & & 1 \\
\hline $5 c$ & $\mathrm{CF}_{3} \mathrm{CO}_{2} \mathrm{H}$ & -78 & 18 & 1 & 20 & 77 & & 2 \\
\hline 5c & $p$-TsOH & rt & 1 & 0.5 & 11 & 76 & 6 & 3 \\
\hline
\end{tabular}

${ }^{a}$ For determination of yields and product ratios see Table II, footnote a. ${ }^{b}$ See Table II, footnote $b$.

shown in Table III, the acid catalysts differ mainly in their reactivity. Strong Lewis acids like $\mathrm{TiCl}_{4}, \mathrm{BF}_{3} \cdot \mathrm{OEt}_{2}$, $\mathrm{EtAlCl}_{2}, \mathrm{Et}_{2} \mathrm{AlCl}, \mathrm{FeCl}_{3}$, and $\mathrm{CF}_{3} \mathrm{CO}_{2} \mathrm{H}$ gave complete conversion of the imines $5 \mathrm{a}, \mathrm{c}$ within $20 \mathrm{~h}$ even at $-78^{\circ} \mathrm{C}$, while $\mathrm{ZnCl}_{2}, p-\mathrm{TsOH}$, or $\mathrm{PPA}$ required room temperature. However, the selectivity was found to be more dependent on the substrate structure than on the type of Lewis acid used. In the case of $5 \mathrm{a}$ best results were achieved with $\mathrm{BF}_{3} \mathrm{OEt}_{2}$ (trans:cis $=98: 1$ ), $\mathrm{TiCl}_{4}$ (trans:cis $=98: 1$ ) or $\mathrm{CF}_{3}$ $\mathrm{CO}_{2} \mathrm{H}$ (trans:cis $=97: 0.4$ ). Even the less selective catalysts like $\mathrm{ZnCl}_{2}$ and $\mathrm{FeCl}_{3}$ gave trans/cis ratios of $91: 3$ and $94: 3$, respectively. When $5 \mathrm{c}$ was used for the cyclization, $\mathrm{ZnCl}_{2}$, $\mathrm{FeCl}_{3}, \mathrm{AlCl}_{3}, \mathrm{EtAlCl}_{2}$, and $\mathrm{Et}_{2} \mathrm{AlCl}$ yielded trans/cis ratios close to $50: 50$ together with $1-2 \%$ of the two minor diastereomers. On the other hand, with $\mathrm{BF}_{3} \cdot \mathrm{OEt}_{2}$ or $\mathrm{CF}_{3^{-}}$ $\mathrm{CO}_{2} \mathrm{H}$ trans/cis ratios were increased to 77:20. The abovementioned strong dependence of reactivity and selectivity on the substrate and the only minor influence of the acidic catalyst is somewhat unexpected because it is known from other Lewis acid catalyzed reactions of imines that they are significantly controlled by the type of Lewis acid. ${ }^{17,18}$ 

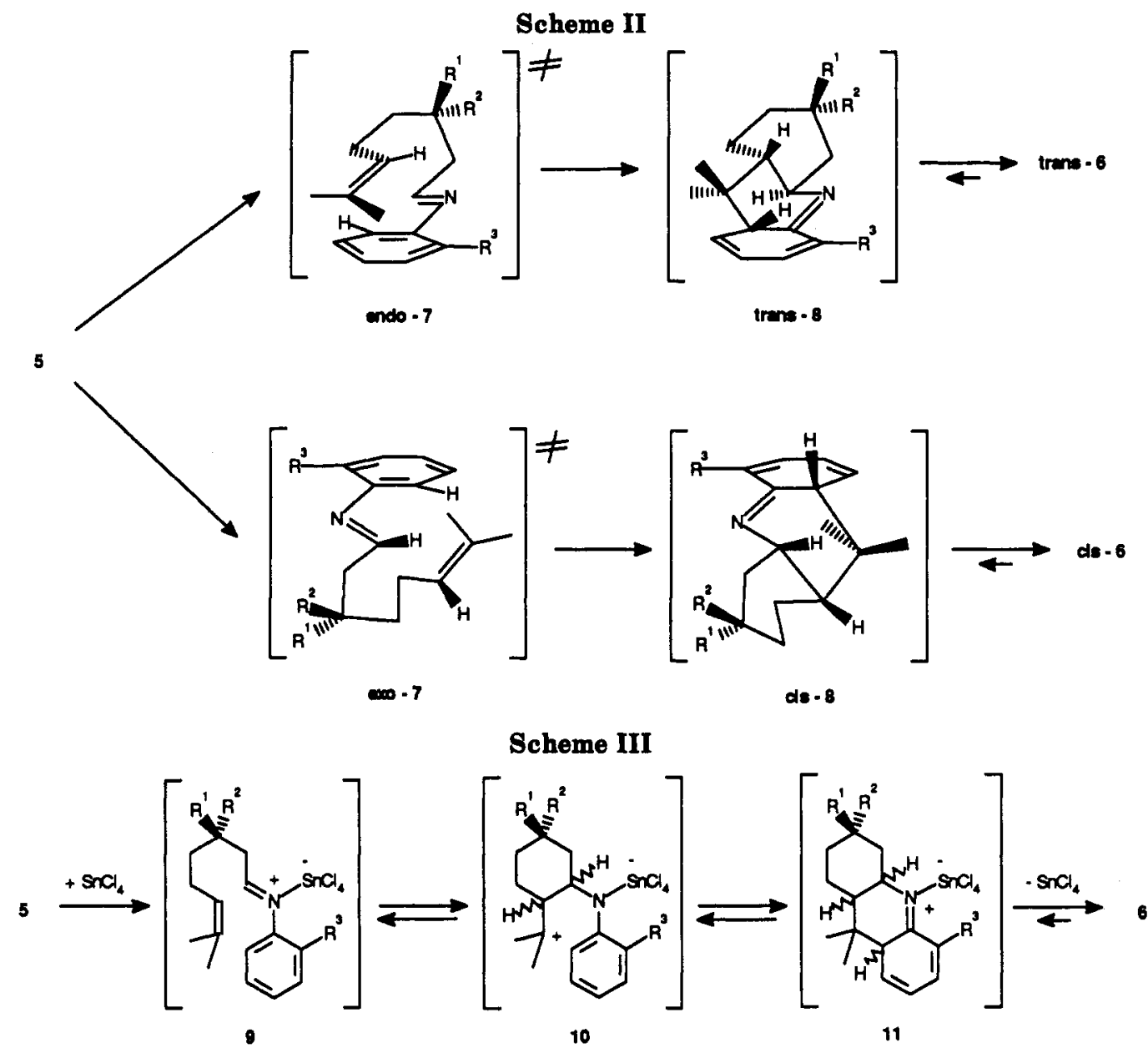

To explain the stereochemical outcome of the cyclization, either a concerted [4+2]-cycloaddition (Scheme II) or a multistep reaction via ionic intermediates (Scheme III) could be proposed. ${ }^{19}$ We favor the cycloaddition mechanism because it explains both the formation of the trans product 6 via the endocyclic transition state endo-7 and the formation of the cis product via the exocyclic transition state exo-7. Due to the steric congestion (H-1/H-5) in exo-7, the endo transition state should be much more favored, especially when the rotational freedom of the C4tether is decreased, e.g., by introducing a gem-dimethyl group at C-3. On the other hand, removal of substituents from the C4-tether should increase the amount of cis product 6, because exo-7 is more easily accessible than in the previous case, thus decreasing the energy difference between endo- and exo-7. However, a stepwise mechanism could not be completely ruled out, in which the terminal cyclohexane ring is built up first by a nucleophilic attack at the iminium ion 9, followed by an electrophilic aromatic substitution initiated by the tertiary carbeniumion 10 . Finally, a tautomerization of the resulting cyclohexadienylimine 11 should give the product 6 . However, we have no NMR-spectroscopic evidence (at $-78^{\circ} \mathrm{C}$ ) for such a cyclohexadienylimine 8 or 11. Probably, the tautomerization is faster than the NMR time scale. When we studied the selectivity as a function of both reaction time

(17) Tietze, L. F.; Wichmann, J. Angew. Chem. 1992, 104, 1091-1092; Angew. Chem., Int. Ed. Engl. 1992, 31, 1079-1080.

(18) Laschat, S.; Kunz, H. J. Org. Chem. 1991, 56, 5883-5889 and references cited therein

(19) The reviewers are gratefully acknowledged for their helpful discussions and suggestions, especially concerning the mechanism of the cyclization. and conversion, we found that the relative amount of the trans product is increasing with increasing reaction time and conversion (see, for example, Table II, entries 3,4 and $10,11)$. However, the isolated products 6 could not be epimerized by treatment with $\mathrm{SnCl}_{4}$ (1.2 equiv) either at room temperature or $-78^{\circ} \mathrm{C}$.

Determination of the Absolute Configuration and Preferred Conformation of cis/trans-6c. The structure of the trans product 6c (diagram) could be completely assigned by first-order interpretation of the 360-MHz 1D${ }^{1} \mathrm{H}-\mathrm{NMR}$ spectrum together with spin decoupling experiments. The large vicinal coupling $J_{4 \mathrm{a}, 9 \mathrm{a}}=10.5 \mathrm{~Hz}$ was taken as a strong evidence for the trans ring fusion. By using the known $(R)$-configuration of $\mathrm{C}-3$ as a stereochemical anchor, the vicinal coupling data of trans-6c were analyzed in terms of dihedral angles from the Karplus relationship, and thus the trans-decalin configuration B with an equatorial methyl group at C-3 was proposed. In structure B H-4ax should give the following couplings (values of dihedral angles are given in parentheses): $J_{4 a x, 4 a}$ $\sim 11 \mathrm{~Hz}\left(180^{\circ}\right), J_{4 a x, 3} \sim 11 \mathrm{~Hz}\left(180^{\circ}\right)$, which were indeed observed (see Experimental Section for details). The other coupling data of trans-6c were in complete agreement with this assignment. On the contrary, the other diastereomeric trans-decalin configuration of $6 \mathbf{c}$ (with an axial methyl group at $\mathrm{C}$-3) should have the following couplings for H-4ax: $J_{4 \mathrm{ax}, 4 \mathrm{a}} \sim 11 \mathrm{~Hz}\left(180^{\circ}\right), J_{4 \mathrm{ax}, 3} \sim 3-4 \mathrm{~Hz}\left(60^{\circ}\right)$. The same analysis was not possible for the cis isomer $6 c$ due to overlapping multiplets of $\mathrm{H}-2 \mathrm{eq}, \mathrm{H}-4-\mathrm{eq}, \mathrm{H}-1 \mathrm{eq}$ and H-9a, H-1ax, H-4ax, respectively. Therefore, NOESY spectra were recorded from both trans-6c and cis-6c. NOE enhancements between $\mathrm{NH}$ and the aromatic methyl group 


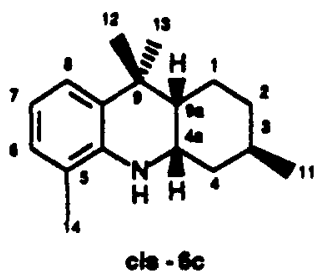<smiles>Cc1cccc2c1N[C@H]1[C@H](C)CC[C@H](C)[C@H]1C2</smiles>

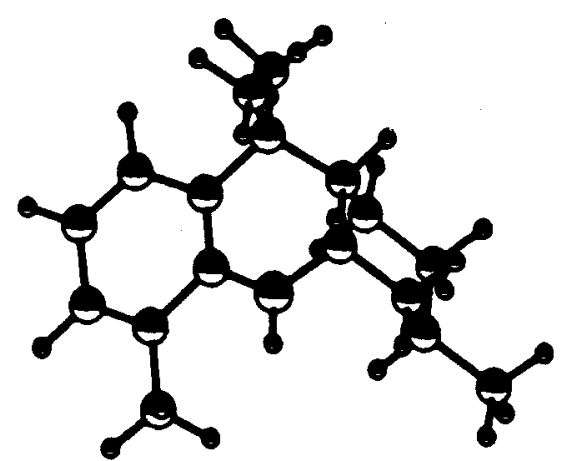

A

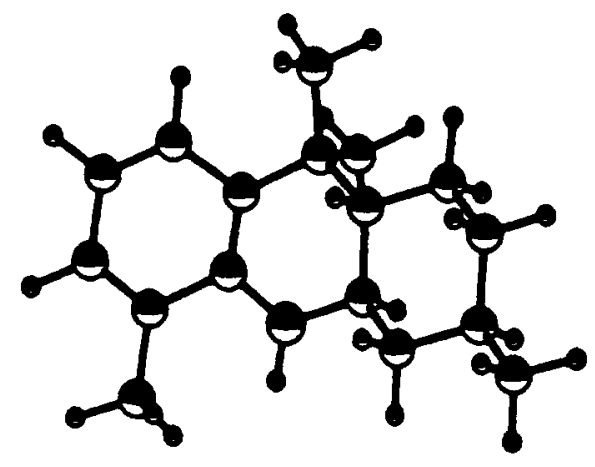

3

(H-14) and between $\mathrm{NH}$ and $\mathrm{H}-4$ eq were observed in both spectra. The NOE between NH and $\mathrm{H}-4 \mathrm{a}$ was smaller in trans-6c compared to cis-6c; however, effects due to saturation transfer from trace amounts of residual water may obscure possible enhancements. The trans decalin configuration $B$ for trans-6c was confirmed by diagnostic NOE's between $\mathrm{H}-4 \mathrm{a} / \mathrm{H}-13$, i.e., the methyl group below the ring system, and $\mathrm{H}-\mathrm{leq} / \mathrm{H}-12$, i.e., the corresponding methyl group above the ring system. For the cis isomer we propose the structure cis-6c and a cis-decalin conformation $\mathbf{A}$ and assign the singlets at 0.98 and $0.93 \mathrm{ppm}$ to the methyl groups below $(\mathrm{H}-13)$ and above $(\mathrm{H}-12)$ the ring system, respectively. Two strong NOE's were observed, i.e., $\mathrm{H}-4 \mathrm{a} / \mathrm{H}-12$ and $\mathrm{H}-4 \mathrm{a} / \mathrm{H}-9 \mathrm{a}$, and smaller NOE's between $\mathrm{H}-4 \mathrm{a} / \mathrm{H}-4 \mathrm{eq}$ and $\mathrm{H}-4 \mathrm{a} / \mathrm{H}-4 \mathrm{ax}$. However, the expected cross peak between protons $\mathrm{H}-12 / \mathrm{H}-9 \mathrm{a}$, which are located on the same side of the ring, could not be detected due to the overlap of multiplets and cross peaks close to the diagonal. In order to check the stereochemical assignment of the cis isomer, a ${ }^{13} \mathrm{C},{ }^{1} \mathrm{H}$ shift correlated $2 \mathrm{D}-\mathrm{NMR}$ spectrum with polarization transfer via the ${ }^{1} J$ couplings was recorded and cross sections, i.e., ${ }^{1} \mathrm{H}-\mathrm{NMR}$ subspectra along individual carbon resonance portions were taken. Besides confirmation of ${ }^{1} \mathrm{H}$ and ${ }^{13} \mathrm{C}$ shift assignments, some of the multiplets could be interpreted as first-order spectra, e.g., H-9a, H-4eq, H-4ax, and H-1ax. Especially the coupling constants of $\mathrm{H}-4 \mathrm{ax}$ (ddd at $0.75 \mathrm{ppm},{ }^{2} J_{4 \mathrm{ax}, 4 \mathrm{eq}}=-13.0 \mathrm{~Hz}$, ${ }^{3} J_{4 \mathrm{ax}, 3}=13.0 \mathrm{~Hz},{ }^{3} J_{4 \mathrm{a}, 4 \mathrm{ax}}=4.0 \mathrm{~Hz}$ ) were taken as evidence for the cis-decalin structure $\mathbf{A}$ for cis-6c. ${ }^{20}$

\section{Conclusion}

The Lewis acid-mediated cyclization of $N$-arylimines described herein allows easy and convenient access to octahydroacridines. Especially the one-pot procedure, which does not require the isolation of the moisture- and oxygen-sensitive imines, seems to be useful for the preparation of octahydroacridines with a variety of substituents on the ring system, just by choosing suitable aldehyde and aniline derivatives. The selectivity of the ring fusion can be adjusted to some extent by the choice of Lewis acid and solvent. It was shown that the absolute stereochemistry and preferred conformation of tricyclic ring systems with one known stereocenter can be elucidated by NMR techniques.

\section{Experimental Section}

All reactions were carried out under an argon atmosphere using standard Schlenk techniques. Solvents were dried and deoxygenated by standard procedures. Analytical TLC was performed on precoated $\mathrm{SiO}_{2} 254 \mathrm{~F}$ plates (0.25-mm thickness) and visualized with a solution of phosphomolybdic acid in $\mathrm{EtOH}(5 \%, \mathrm{v} / \mathrm{v})$. Flash chromatography was carried out with silica gel 60 (230400 mesh). Melting points were measured on a capillary melting point apparatus and are uncorrected. IR spectra were recorded on an FT-IR spectrometer. Optical rotations were measured in 1-dm cells ( $1 \mathrm{~mL}$ capacity) at ambient temperature. Mass spectra were obtained at an ionization potential of $70 \mathrm{eV}$. For GC analysis a HP5 fused silica capillary column $(0.32-\mathrm{mm}$ i.d., length $25 \mathrm{~m})$ was used. 7-Methyl-6-octenal and 3,3,7-trimethyl-6-octenal were prepared according to literature procedues; ${ }^{21}(R)-(+)$-citronellal was commercially available.

General Procedure for the Preparation of N-Arylimines 5. To a solution of aniline or toluidine $(1.00 \mathrm{mmol})$ in pentane $(10 \mathrm{~mL})$ was added aldehyde $3(1.00 \mathrm{mmol})$ and $4-\AA$ molecular sieves, and the mixture was stirred overnight at room temperature. After filtration via Celite the solvent was removed, and the crude products were used without further purification.

N-(3,3,7-Trimethyl-6-octenylidene)-a-toluidine (5a): 255 $\mathrm{mg}$ (quant.) of a colorless oil; ${ }^{1} \mathrm{H}-\mathrm{NMR}\left(200 \mathrm{MHz}, \mathrm{CDCl}_{3}\right.$ ) $\delta 7.86$ $(\mathrm{t}, J=5.7 \mathrm{~Hz}, 1 \mathrm{H}, \mathrm{HC}=\mathrm{N}), 7.24-7.08\left(\mathrm{~m}, 3 \mathrm{H}, \mathrm{H}-4^{\prime}, \mathrm{H}-5^{\prime}, \mathrm{H}-6^{\prime}\right)$, 6.78-6.74 (m, $\left.1 \mathrm{H}, \mathrm{H}-3^{\prime}\right), 5.19(\mathrm{~m}, 1 \mathrm{H}, \mathrm{H}-6), 2.46(\mathrm{~d}, J=5.7 \mathrm{~Hz}$, $2 \mathrm{H}, \mathrm{H}-2), 2.34$ [s, $\left.3 \mathrm{H},\left(\mathrm{C}-2^{\prime}\right) \mathrm{CH}_{3}\right], 2.20-2.09(\mathrm{~m}, 2 \mathrm{H}, \mathrm{H}-5), 1.76$ (d, $J=1.0 \mathrm{~Hz}, 3 \mathrm{H}, \mathrm{H}-9), 1.69$ (s, $3 \mathrm{H}, \mathrm{H}-8), 1.48-1.35$ (m, $2 \mathrm{H}$, $\mathrm{H}-4), 1.06$ [s, $\left.6 \mathrm{H},(\mathrm{C}-3) \mathrm{Me}_{2}\right] ;{ }^{13} \mathrm{C}-\mathrm{NMR}\left(50 \mathrm{MHz}, \mathrm{CDCl}_{3}\right) \delta 164.5$, $151.9,131.0,130.3,129.9,126.5,124.6,118.3,48.1,42.6,33.8,29.7$, $27.3,25.6,22.7,17.7,17.5$; IR (film) $1653,1457,745 \mathrm{~cm}^{-1}$; MS (EI) $m / z 257$ (M, 23). 242 (26), 174 (35), 158 (33), 133 (35), 118 (54), 107 (40), 95 (42), 91 (37), 84 (41), 69 (82), 55 (100); HRMS calcd for $\mathrm{C}_{18} \mathrm{H}_{27} \mathrm{~N} 257.2143$, found 257.2137 .

$\boldsymbol{N}$-(3,3,7-Trimethyl-6-octenylidene)aniline (5b): $247 \mathrm{mg}$ (quant.) of a colorless oil; ${ }^{1} \mathrm{H}-\mathrm{NMR}\left(200 \mathrm{MHz}^{\mathrm{CDCl}} \mathrm{CDC}_{3}\right) \delta 7.90(\mathrm{t}$, $J=5.7 \mathrm{~Hz}, 1 \mathrm{H}, \mathrm{HC}=\mathrm{N}), 7.32\left({ }^{\prime}{ }^{\prime}{ }^{\prime}, J=7.1 \mathrm{~Hz}, 2 \mathrm{H}, \mathrm{H}-2^{\prime}, \mathrm{H}-6^{\prime}\right.$ ), 7.17 ( “d”, $J=7.3 \mathrm{~Hz}, 1 \mathrm{H}, \mathrm{H}-4^{\prime}$ ), 7.01 ( “ ${ }^{\mathrm{t}}$ ”, $J=7.1 \mathrm{~Hz}, 2 \mathrm{H}, \mathrm{H}-3^{\prime}$, $\left.\mathrm{H}-5^{\prime}\right), 5.12$ (m, $1 \mathrm{H}, \mathrm{H}-6$ ), 2.39 (d, $J=5.7 \mathrm{~Hz}, 2 \mathrm{H}, \mathrm{H}-2$ ), 2.12-1.98 (m, $2 \mathrm{H}, \mathrm{H}-5), 1.69$ (d, $J=1.0 \mathrm{~Hz}, 3 \mathrm{H}, \mathrm{H}-9), 1.62$ (s, $3 \mathrm{H}, \mathrm{H}-8)$, 1.40-1.21 (m, $2 \mathrm{H}, \mathrm{H}-4), 1.06$ [s, $6 \mathrm{H},(\mathrm{C}-3) \mathrm{Me}_{2}$ ]; ${ }^{13} \mathrm{C}-\mathrm{NMR}(50$ $\left.\mathrm{MHz}, \mathrm{CDCl}_{3}\right) \delta 164.4,152.4,131.1,129.9,128.9,125.3,124.6,120.5$, 48.1, 42.6, 33.9, 29.6, 27.3, 25.6, 22.7, 17.5; IR (film) 1653, 1451, $694 \mathrm{~cm}^{-1}$; MS (EI) $\mathrm{m} / z 243$ (M, 26), 228 (65), $160(90), 147$ (77), $118(100), 104$ (50), 91 (50), 77 (89), 69 (74), 55 (85); HRMS calcd for $\mathrm{C}_{17} \mathrm{H}_{25} \mathrm{~N} 243.1987$, found 243.1983 .

$\boldsymbol{N}$-(R)-(3,7-Trimethyl-6-octenylidene)-o-toluidine (5c): 230 $\mathrm{mg}$ (quant.) of a colorless oil; $[\alpha]^{20} \mathrm{D}+4.6^{\circ}\left(c 1.00 ; \mathrm{CHCl}_{3}\right) ;{ }^{1} \mathrm{H}-$ NMR $\left(200 \mathrm{MHz}, \mathrm{CDCl}_{3}\right) \delta 7.75(\mathrm{t}, J=5.5 \mathrm{~Hz}, 1 \mathrm{H}, \mathrm{HC}=\mathrm{N})$, 7.19-7.06 (m, 3 H, H-4', H-5', H-6' $), 6.72$ (dd, $J=6.3,1.9 \mathrm{~Hz}, 1$

(20) The stereochemical assignment of the other cyclization products $6 a, b, d-f$ was deduced from the known configuration of cis/trans-6c because the corresponding cis and trans isomers showed similar couplings and chemical shifts for $\mathrm{H}-4 \mathrm{a}$.

(21) Sakane, S.; Maruoka, K.; Yamamoto, H. Tetrahedron 1986, 42, 2203-2209. 
H, H-3') 5.14 (m, $1 \mathrm{H}, \mathrm{H}-6$ ), 2.57-2.33 (m, $2 \mathrm{H}, \mathrm{H}-2$ ), 2.29 [s, 3 $\left.\mathrm{H},\left(\mathrm{C}-2^{\prime}\right) \mathrm{CH}_{3}\right], 2.26-1.85$ (m, $\left.3 \mathrm{H}, \mathrm{H}-5, \mathrm{H}-3\right), 1.71$ (s, 3 H, H-8), 1.64 (s, $3 \mathrm{H}, \mathrm{H}-9), 1.63-1.23(\mathrm{~m}, 2 \mathrm{H}, \mathrm{H}-4), 1.05[\mathrm{~d}, J=6.6 \mathrm{~Hz}$, $3 \mathrm{H},(\mathrm{C}-3) \mathrm{CH}_{3}$ ]; ${ }^{13} \mathrm{C}-\mathrm{NMR}\left(50 \mathrm{MHz}, \mathrm{CDCl}_{3}\right) \delta 165.4,151.8,131.4$, $130.3,129.9,126.6,124.9,124.4,118.3,43.6,36.9,30.6,25.6,25.4$, $19.7,17.7,17.6$; IR (film) $1654,1487,1457,747 \mathrm{~cm}^{-1}$; MS (EI) $\mathrm{m} / \mathrm{z}$ 229 (M, 28), 214 (27), 172 (26), 147 (94), 146 (100), 119 (89), 117 (88), 93 (41), 85 (37), $77(91), 69(64)$; HRMS calcd for $\mathrm{C}_{16} \mathrm{H}_{23} \mathrm{~N}$ 229.1830 , found 229.1836 .

$N$-(R)-(3,7-Trimethyl-6-octenylidene)aniline (5d): $240 \mathrm{mg}$ (quant.) of a colorless oil; $[\alpha]^{20} \mathrm{D}+11.1^{\circ}\left(c 1.00 ; \mathrm{CHCl}_{3}\right) ;{ }^{1} \mathrm{H}-\mathrm{NMR}$ $\left(200 \mathrm{MHz}, \mathrm{CDCl}_{3}\right) \delta 7.83(\mathrm{t}, J=5.5 \mathrm{~Hz}, 1 \mathrm{H}, \mathrm{HC}=\mathrm{N}), 7.36-7.28$ (m, $2 \mathrm{H}, \mathrm{H}-3^{\prime}$ ), 7.19-7.12 (m, $\left.1 \mathrm{H}, \mathrm{H}-4^{\prime}\right), 7.04-7.00$ (m, $2 \mathrm{H}, \mathrm{H}-2^{\prime}$ ), 5.12 (m, $1 \mathrm{H}, \mathrm{H}-6), 2.44$ (" $\mathrm{t}$ ", $J=5.4 \mathrm{~Hz}, 1 \mathrm{H}, \mathrm{H}-2 \mathrm{a}), 2.33$ (dd, $J=7.7,5.6 \mathrm{~Hz}, 1 \mathrm{H}, \mathrm{H}-2 \mathrm{~b}), 2.11-1.91(\mathrm{~m}, 3 \mathrm{H}, \mathrm{H}-3, \mathrm{H}-5), 1.69$ (s, $3 \mathrm{H}, \mathrm{H}-8), 1.62$ (s, $3 \mathrm{H}, \mathrm{H}-9), 1.62-120$ (m, $2 \mathrm{H}, \mathrm{H}-4), 1.02$ [d, $\left.J=7.7 \mathrm{~Hz}, 3 \mathrm{H},(\mathrm{C}-3) \mathrm{CH}_{3}\right] ;{ }^{13} \mathrm{C}-\mathrm{NMR}\left(50 \mathrm{MHz}, \mathrm{CDCl}_{3}\right) \delta 165.9$, $152.3,131.3,128.8,125.2,124.3,120.4,43.6,36.9,30.6,25.6,24.5$, 19.6, 17.8; IR (film) $1654,1596,1486,755,695 \mathrm{~cm}^{-1}$; MS (EI) $\mathrm{m} / \mathrm{z}$ 243 (M, 12), 228 (16), 214 (16), 160 (65), 146 (23), 118 (100), 107 (49), 91 (64), 77 (22), 69 (28), 65 (41), 57 (25); HRMS calcd for $\mathrm{C}_{17} \mathrm{H}_{25} \mathrm{~N}$ 243.1987, found 243.1995.

$\boldsymbol{N}$-(7-Methyl-6-octenylidene)-a-toluidine (5e): $230 \mathrm{mg}$ (quant.) of a colorless oil; ${ }^{1} \mathrm{H}-\mathrm{NMR}\left(200 \mathrm{MHz}, \mathrm{CDCl}_{3}\right) \delta 7.76(\mathrm{t}$, $J=5.7 \mathrm{~Hz}, 1 \mathrm{H}, \mathrm{HC}=\mathrm{N}), 7.21-7.06\left(\mathrm{~m}, 3 \mathrm{H}, \mathrm{H}-4^{\prime}, \mathrm{H}-5^{\prime}, \mathrm{H}-6^{\prime}\right)$, 6.77-6.52 (m, $\left.1 \mathrm{H}, \mathrm{H}-3^{\prime}\right), 5.15$ (m, $\left.1 \mathrm{H}, \mathrm{H}-6\right), 2.55-2.45$ (m, $2 \mathrm{H}$, $\mathrm{H}-2), 2.29\left[\mathrm{~s}, 3 \mathrm{H},\left(\mathrm{C}-2^{\prime}\right) \mathrm{CH}_{3}\right], 2.18-1.98(\mathrm{~m}, 4 \mathrm{H}, \mathrm{H}-3, \mathrm{H}-5), 1.73$ (s, 3 H, H-8), 1.65 (s, 3 H, H-9), 1.57-1.31 (m, $2 \mathrm{H}, \mathrm{H}-4)$; ${ }^{13} \mathrm{C}-\mathrm{NMR}$ $\left(50 \mathrm{MHz}_{\mathrm{CDCl}}\right.$ ) $\delta 165.7,131.0,130.2,129.9,126.5,124.9,124.3$, 118.2, 36.4, 29.6, 29.4, 27.7, 25.6, $\left(2 \times \mathrm{CH}_{3}\right), 17.6$; IR (film) 1655, $1456,746 \mathrm{~cm}^{-1}$; MS (EI) $\mathrm{m} / z 229(\mathrm{M}, 16), 214$ (19), 161 (27), 146 (33), 118 (72), 107 (39), 91 (42), 83 (58), 69 (78), 57 (100); HRMS calcd for $\mathrm{C}_{16} \mathrm{H}_{23} \mathrm{~N} 229.1830$, found 229.1827 .

$\boldsymbol{N}$-(7-Methyl-6-octenylidene)aniline (5f): $212 \mathrm{mg}$ (quant.) of a coloriess oil; ${ }^{1} \mathrm{H}-\mathrm{NMR}\left(200 \mathrm{MHz}, \mathrm{CDCl} l_{3}\right) \delta 7.87(\mathrm{t}, J=5.0$ $\mathrm{Hz}, 1 \mathrm{H}, \mathrm{HC}=\mathrm{N}$ ), 7.36-6.50 (m, $\left.5 \mathrm{H}, \mathrm{H}-2^{\prime}, \mathrm{H}-3^{\prime}, \mathrm{H}-4^{\prime}, \mathrm{H}^{\prime} \mathrm{5}^{\prime}, \mathrm{H}-6^{\prime}\right)$, 5.12 (m, $1 \mathrm{H}, \mathrm{H}-6), 2.70-2.51$ (m, $1 \mathrm{H}, \mathrm{H}-2 \mathrm{a}), 2.10-1.98(\mathrm{~m}, 5 \mathrm{H}$, $\mathrm{H}-3, \mathrm{H}-5, \mathrm{H}-2 \mathrm{~b}), 1.71$ (s, 3 H, H-8), 1.61 (s, 3 H, H-9), 1.80-1.20 $(\mathrm{m}, 2 \mathrm{H}, \mathrm{H}-4) ;{ }^{13} \mathrm{C}-\mathrm{NMR}\left(50 \mathrm{MHz}, \mathrm{CDCl}_{3}\right) \delta 166.4,132.0,131.0$, 126.6, 124.3, 118.2, 36.5, 29.8, 29.3, 27.8, $25.7\left(2 \times \mathrm{CH}_{3}\right)$; IR (film) $1653,1601,1501,1487,747,693 \mathrm{~cm}^{-1}$; MS (EI) $\mathrm{m} / \mathrm{z}(\mathrm{M}, 25), 200$ (35), $185(28), 147(44), 132(39), 105$ (48), 95 (50), 84 (49), 69 (57), 57 (100), $55(96)$; HRMS calcd for $\mathrm{C}_{15} \mathrm{~N}_{21} \mathrm{~N} 215.1674$, found 215.1679 .

General Procedure for the Cyclization of N-Arylimines 5. (For temperatures and reaction times see Tables I-III.) Method A. To a solution of imine $5(0.50 \mathrm{mmol})$ in $\mathrm{CH}_{2} \mathrm{Cl}_{2}(14$ $\mathrm{mL})$ was added a Lewis acid $(0.05 \mathrm{mmol})$ over $30 \mathrm{~min}$, and the mixture was stirred until GC showed no more conversion. $\mathrm{NaOH}$ ( $2 \mathrm{~N}, 50 \mathrm{~mL}$ ) was added, and the mixture was extracted with $\mathrm{CH}_{2} \mathrm{Cl}_{2}(3 \times 100 \mathrm{~mL})$. After the combined organic layers were washed with saturated $\mathrm{NaCl}(200 \mathrm{~mL})$ and dried over $\mathrm{MgSO}_{4}$, the crude products were purified by flash chromatography (100:1 hexanes-ethyl acetate).

Method B. To a precooled solution $\left(-78{ }^{\circ} \mathrm{C}\right)$ aniline or o-toluidine $(0.50 \mathrm{mmol})$ in $\mathrm{CH}_{2} \mathrm{Cl}_{2}(14 \mathrm{~mL})$ was added a Lewis acid $(0.05 \mathrm{mmol})$ over $30 \mathrm{~min}$. Then aldehyde $3(0.50 \mathrm{mmol})$ in $\mathrm{CH}_{2} \mathrm{Cl}_{2}(1 \mathrm{~mL})$ was added slowly over $1 \mathrm{~h}$ and the reaction mixture was stirred until completion and worked up as described above.

3,3,5,9,9-Pentamethyloctahydroacridine (trans-6a): 111 mg $(86 \%)$ of colorless crystals; mp $82^{\circ} \mathrm{C} ;{ }^{1} \mathrm{H}-\mathrm{NMR}(200 \mathrm{MHz}$, $\mathrm{CDCl}_{3}$ ) $\delta 7.18(\mathrm{~d}, J=7.7 \mathrm{~Hz}, 1 \mathrm{H}, \mathrm{H}-8), 6.86$ (dd, $J=7.5,0.7 \mathrm{~Hz}$, $1 \mathrm{H}, \mathrm{H}-6), 6.58(\mathrm{t}, J=7.5 \mathrm{~Hz}, 1 \mathrm{H}, \mathrm{H}-7), 3.43$ (s, broad, $1 \mathrm{H}, \mathrm{NH}$ ), 3.30 (ddd, $J=10.5,10.4,3.9 \mathrm{~Hz}, 1 \mathrm{H}, \mathrm{H}-4 \mathrm{a}$ ), 2.12 (s, $3 \mathrm{H}, \mathrm{H}-15$ ), 1.78-1.50 (m, 4 H, H-2eq, H-4eq, H-leq, H-9a), 1.45-1.17 (m, 3 H, H-1ax, H-2ax, H-4ax), 1.32 (s, 3 H, H-13), 1.13 (s, 3 H, H-14), 1.04 (s, $6 \mathrm{H}, \mathrm{H}-11, \mathrm{H}-12)$; ${ }^{13} \mathrm{C}-\mathrm{NMR}\left(50 \mathrm{MHz}, \mathrm{CDCl}_{3}\right.$ ) $\delta 140.7$, $130.0,127.5,124.4,120.1,116.1,47.5,47.4,47.3,39.3,34.9,33.0$, $31.0,27.2,26.9,25.1,20.9,17.4$; IR (film) $3407,1598,1478,1362$, $743 \mathrm{~cm}^{-1}$; MS (EI) m/z 257 (M, 55), 242 (100), 158 (56), 91 (29), 69 (73), 55 (60); HRMS calcd for $\mathrm{C}_{18} \mathrm{H}_{27} \mathrm{~N}$ 257.2143, found 257.2131. Anal. Calcd for $\mathrm{C}_{18} \mathrm{H}_{27} \mathrm{~N}$ : C, 83.98; $\mathrm{H}, 10.57 ; \mathrm{N}, 5.45$. Found: C, 83.62; H, 10.61; N, 5.40.

$3,3,9,9$-Tetramethyloctahydroacridine (trans-6b). $87 \mathrm{mg}$ (72\%) of colorless crystals; mp $69^{\circ} \mathrm{C} ;{ }^{1} \mathrm{H}-\mathrm{NMR}\left(200 \mathrm{MHz}, \mathrm{CDCl}_{3}\right)$ $\delta 7.28(\mathrm{~d}, J=7.4 \mathrm{~Hz}, 1 \mathrm{H}, \mathrm{H}-8), 7.00(\mathrm{t}, J=7.4 \mathrm{~Hz}, 1 \mathrm{H}, \mathrm{H}-6)$,
6.70 (t, $J=7.4 \mathrm{~Hz}, 1 \mathrm{H}, \mathrm{H}-7$ ), 6.47 (d, $J=7.4 \mathrm{~Hz}, 1 \mathrm{H}, \mathrm{H}-5$ ), 3.53 (s, broad, $1 \mathrm{H}, \mathrm{NH}$ ), 3.27 (ddd, $J=10.5,10.4,4.1 \mathrm{~Hz}, 1 \mathrm{H}, \mathrm{H}-4 \mathrm{a}$ ), 1.81-1.47 (m, $4 \mathrm{H}$, H-1eq, H-2eq, H-4eq, H-9a), 1.40 (s, $3 \mathrm{H}$, H-13), 1.40-1.27 (m, 3 H, H-1ax, H-2ax, H-4ax), 1.20 (s, $3 \mathrm{H}$, $\mathrm{H}-14), 1.04$ (s, $6 \mathrm{H}, \mathrm{H}-11, \mathrm{H}-12) ;{ }^{13} \mathrm{C}-\mathrm{NMR}\left(50 \mathrm{MHz}^{\left.-\mathrm{CDCl}_{3}\right) \delta}\right.$ 143.1, 131.2, 126.5, 126.4, 116.8, 113.7, 47.8, 47.3, 47.1, 39.3, 34.8, $33.0,30.9,27.2,26.7,25.1,20.9,17.4$; IR (film) 3394, 1605, 1582, $1498,743 \mathrm{~cm}^{-1}$; MS (EI) m/z 243 (M, 20), $228(54), 158(24), 149$ (28), 69 (77), 55 (100); HRMS calcd for $\mathrm{C}_{17} \mathrm{H}_{25} \mathrm{~N} 243.1987$, found 243.1983.

(3R)-3,5,9,9-Tetramethyloctylhydroacridine (6c). Flash chromatography yielded $31 \mathrm{mg}(26 \%)$ of a pale yellow oil as the first fraction ( $98 \%$ cis by GC), $8 \mathrm{mg}(7 \%)$ of a pale yellow oil as the second fraction ( $35 \%$ cis, $61 \%$ trans by GC), and $43 \mathrm{mg}(36 \%$ ) of colorless crystals as the third fraction ( $99 \%$ trans by GC). cis-6c: $[\alpha]^{20} \mathrm{D}-43.0^{\circ}\left(\mathrm{c} 1.00 ; \mathrm{CHCl}_{3}\right) ;{ }^{\mathrm{I}} \mathrm{H}-\mathrm{NMR}\left(200 \mathrm{MHz}, \mathrm{C}_{6} \mathrm{D}_{6}\right)$ $\delta 6.86$ ( “d", $J=7.5 \mathrm{~Hz}, 1 \mathrm{H}, \mathrm{H}-8$ ), 6.67 ( $" \mathrm{ddq}^{\prime}, J=7.5,1.6,0.8$ $\mathrm{Hz}, 1 \mathrm{H}, \mathrm{H}-6$ ), 6.46 (t, $J=7.5 \mathrm{~Hz}, 1 \mathrm{H}, \mathrm{H}-7$ ), 3.41 (dddd, $J_{4 \mathrm{a}, 9 \mathrm{a}}$ $\left.=4.8 \mathrm{~Hz}, J_{4 \mathrm{a}, \mathrm{NH}}=4 \mathrm{~Hz}, J_{4 \mathrm{a}, 4 \mathrm{ax}}=4 \mathrm{~Hz}, J_{4 \mathrm{a}, 4 \mathrm{eq}}=4 \mathrm{~Hz}, 1 \mathrm{H}, \mathrm{H}-4 \mathrm{a}\right)$, 2.80 (s, broad, $1 \mathrm{H}, \mathrm{NH}$ ), 1.63 (s, $3 \mathrm{H}, \mathrm{H}-14), 1.50-1.37$ (m, $1 \mathrm{H}$, $\mathrm{H}-3$ ), $1.32-1.22$ (m, $1 \mathrm{H}, \mathrm{H}-2 \mathrm{eq}$ ), 1.22 (dddd, $J_{4 \mathrm{ax}, 4 \mathrm{eq}}=13.0 \mathrm{~Hz}$, $J_{4 a, 4 e q}=4 \mathrm{~Hz}, J_{4 \mathrm{eq}, 3}=4 \mathrm{~Hz}, J_{4 \mathrm{eq}, 2 \mathrm{eq}}=4 \mathrm{~Hz}, 1 \mathrm{H}, \mathrm{H}-4 \mathrm{eq}$ ), 1.18 ("dd", $\left.J_{\text {lax, leq }}=13.0 \mathrm{~Hz}, J_{9 \mathrm{a}, \text { leq }}=4.8 \mathrm{~Hz}, 1 \mathrm{H}, \mathrm{H}-1 \mathrm{eq}\right), 0.98(\mathrm{~s}, 3 \mathrm{H}, \mathrm{H}-13)$, $0.93(\mathrm{~s}, 3 \mathrm{H}, \mathrm{H}-12), 0.80$ (ddd, $J_{9 \mathrm{a}, 1 \mathrm{ax}}=11.7 \mathrm{~Hz}, J_{4 \mathrm{a}, 9 \mathrm{a}}=4.8 \mathrm{~Hz}$, $J_{9 \mathrm{a}, 1 \mathrm{eq}}=4.8 \mathrm{~Hz}, 1 \mathrm{H}, \mathrm{H}-9 \mathrm{a}$ ), 0.76 (dddd, $J_{1 \mathrm{ax}, 1 \mathrm{leq}}=13.0 \mathrm{~Hz}, J_{1 \mathrm{ax}, 2 \mathrm{ax}}$ $\left.=13.0 \mathrm{~Hz}, J_{9 \mathrm{a}, 1 \mathrm{ax}}=11.7 \mathrm{~Hz}, J_{\text {lax }, 2 \mathrm{eq}}=5.0 \mathrm{~Hz}, 1 \mathrm{H}, \mathrm{H}-1 \mathrm{ax}\right), 0.75$ (ddd, $J_{4 \mathrm{ax}, 4 \mathrm{eq}}=13.0 \mathrm{~Hz}, J_{4 \mathrm{ax}, 3}=13.0 \mathrm{~Hz}, J_{4 \mathrm{a}, 4 \mathrm{ax}}=4 \mathrm{~Hz}, 1 \mathrm{H}$, $\mathrm{H}-4 \mathrm{ax}$ ), 0.57 (d, $J=6.6 \mathrm{~Hz}, 3 \mathrm{H}, \mathrm{H}-11$ ), $0.62-0.39$ (m, $1 \mathrm{H}, \mathrm{H}-2 \mathrm{ax}$ ); ${ }^{13} \mathrm{C}-\mathrm{NMR}$ (50 MHz, $\mathrm{CDCl}_{3}$ ) $\delta 141.1$ (C-10a), 128.1 (C-8), 128.0 (C-8a), 124.4 (C-6), 119.6 (C-5), 116.6 (C-7), 47.1 (C-4a), 44.7 (C9a), 41.6 (C-4), 35.8 (C-9), 35.1 (C-2), 34.3 (C-12), 26.6 (C-13), 25.7 (C-3), 23.1 (C-1), 22.6 (C-11), 17.5 (C-14); IR (film) 3432, $1598,1477,1300,740 \mathrm{~cm}^{-1}$; HRMS calcd for $\mathrm{C}_{17} \mathrm{H}_{25} \mathrm{~N} 243.1987$, found 243.1981. trans-6c: $\mathrm{mp} 68^{\circ} \mathrm{C}$; $[\alpha]^{20} \mathrm{D}+58.0^{\circ}$ (c 1.00 ; $\left.\mathrm{CHCl}_{3}\right) ;{ }^{1} \mathrm{H}-\mathrm{NMR}\left(200 \mathrm{MHz}, \mathrm{C}_{6} \mathrm{D}_{6}\right) \delta 6.63(\mathrm{~d}, J=7.6 \mathrm{~Hz}, 1 \mathrm{H}$, $\mathrm{H}-8$ ), 6.39 ( “ddq", $J=7.6,1.6,0.8 \mathrm{~Hz}, 1 \mathrm{H}, \mathrm{H}-6$ ), 6.21 (t, $J=7.6$ $\mathrm{Hz}, 1 \mathrm{H}, \mathrm{H}-7$ ), 2.92 (s, broad, $1 \mathrm{H}, \mathrm{NH}$ ), 2.70 (dddd, $J_{4 \mathrm{a}, 4 \mathrm{ax}}=10.7$, $\left.J_{4 \mathrm{a}, 9 \mathrm{a}}=10.5 \mathrm{~Hz}, J_{4 \mathrm{a}, 4 \mathrm{eq}}=4.2 \mathrm{~Hz}, J_{4 \mathrm{a}, \mathrm{NH}}=1.3 \mathrm{~Hz}, 1 \mathrm{H}, \mathrm{H}-4 \mathrm{a}\right), 1.70$ (s, $3 \mathrm{H}, \mathrm{H}-14$ ), 1.38 (dddd, $J_{1 \mathrm{ax}, 1 \mathrm{eq}}=13.0 \mathrm{~Hz}, J_{1 \mathrm{eq}, 9 \mathrm{a}}=3.0 \mathrm{~Hz}$, $J_{\text {leq,2eq }}=3.0 \mathrm{~Hz}, J_{1 \mathrm{eq}, 2 \mathrm{ax}}=3.0 \mathrm{~Hz}, 1 \mathrm{H}, \mathrm{H}-1$ eq), 1.30 (ddddd, $J_{2 \mathrm{ax}, 2 \mathrm{eq}}$ $=12.5 \mathrm{~Hz}, J_{2 \mathrm{eq}, 3}=3.1 \mathrm{~Hz}, J_{1 \mathrm{eq}, 2 \mathrm{eq}}=3.1 \mathrm{~Hz}, J_{1 \mathrm{ax}, 2 \mathrm{eq}}=3.1 \mathrm{~Hz}, J_{4 \mathrm{eq}, 2 \mathrm{eq}}$ $=2.1 \mathrm{~Hz}, 1 \mathrm{H}, \mathrm{H}-2 \mathrm{eq}$ ), 1.21 (dddd, $J_{4 \mathrm{ax}, 4 \mathrm{eq}}=12.0 \mathrm{~Hz}, J_{4 \mathrm{a}, 4 \mathrm{eq}}=4.2$ $\left.\mathrm{Hz}, J_{4 \mathrm{eq}, 3}=3.0 \mathrm{~Hz}, J_{4 \mathrm{eq}, 2 \mathrm{eq}}=2.1 \mathrm{~Hz}, 1 \mathrm{H}, \mathrm{H}-4 \mathrm{eq}\right), 0.98(\mathrm{~s}, 3 \mathrm{H}$, $\mathrm{H}-12$ ), $1.02-0.93(\mathrm{~m}, 1 \mathrm{H}, \mathrm{H}-3), 0.91$ (ddd, $J_{1 \mathrm{ax}, 9 \mathrm{a}}=12.0 \mathrm{~Hz}, J_{4 \mathrm{a}, 9 \mathrm{a}}$ $\left.=10.5 \mathrm{~Hz}, J_{1 \mathrm{eq}, 9 \mathrm{a}}=3.0 \mathrm{~Hz}, 1 \mathrm{H}, \mathrm{H}-9 \mathrm{a}\right), 0.82(\mathrm{~s}, 3 \mathrm{H}, \mathrm{H}-13), 0.68$ (dddd, $J_{1 \mathrm{ax}, 1 \mathrm{eq}}=13.0 \mathrm{~Hz}, J_{1 \mathrm{ax}, 2 \mathrm{ax}}=13.0 \mathrm{~Hz}, J_{1 \mathrm{ax}, 9 \mathrm{a}}=12.0 \mathrm{~Hz}$, $J_{1 \mathrm{ax}, 2 \mathrm{eq}}=3.1 \mathrm{~Hz}, 1 \mathrm{H}, \mathrm{H}-1 \mathrm{ax}$ ), 0.58 (ddd, $J_{4 \mathrm{ax}, 4 \mathrm{eq}}=12.0 \mathrm{~Hz}, J_{4 \mathrm{ax}, 3}$ $\left.=12.0 \mathrm{~Hz}, J_{4 \mathrm{a}, 4 \mathrm{ax}}=10.7 \mathrm{~Hz}, 1 \mathrm{H}, \mathrm{H}-4 \mathrm{ax}\right), 0.57$ (d, $J=6.5 \mathrm{~Hz}, 3$ $\mathrm{H}, \mathrm{H}-11$ ), 0.49 (dddd, $J_{1 \mathrm{ax}, 2 \mathrm{ax}}=13.0 \mathrm{~Hz}, J_{2 \mathrm{ax}, 2 \mathrm{eq}}=12.5 \mathrm{~Hz}, J_{2 \mathrm{ax}, 3}$ $\left.=11.6 \mathrm{~Hz}, J_{1 \mathrm{eq}, 2 \mathrm{ax}}=3.0 \mathrm{~Hz}, 1 \mathrm{H}, \mathrm{H}-2 \mathrm{ax}\right) ;{ }^{13} \mathrm{C}-\mathrm{NMR}(50 \mathrm{MHz}$, $\mathrm{CDCl}_{3}$ ) $\delta 141.3$ (C-10a), 130.7 (C-8a), 128.3 (C-6), 124.8 (C-8), 120.1 (C-5), 116.8 (C-7), 50.8 (C-4a), 47.1 (C-9a), 43.7 (C-4), 35.3 (C-2), 35.0 (C-9), 31.1 (C-12), 27.3 (C-13), 27.0 (C-3), 25.0 (C-1), 22.4 (C-11), 17.5 (C-14); IR (film) 3434, 1598, 1478, 1305, 739 $\mathrm{cm}^{-1}$; MS (EI) $m / z 243(\mathrm{M}, 40), 228(100), 172(27), 158(35), 146$ (30), 97 (21), 57 (26); HRMS calcd for $\mathrm{C}_{17} \mathrm{H}_{25} \mathrm{~N} 243.1987$, found 243.1990. Anal. Calcd for $\mathrm{C}_{17} \mathrm{H}_{25} \mathrm{~N}$ : C, 83.89; $\mathrm{H}, 10.35 ; \mathrm{N}, 5.76$. Found: C, 83.66; H, 10.60; N, 5.93.

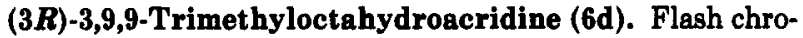
matography yielded $28 \mathrm{mg}$ ( $23 \%$ ) of a yellow oil as the first fraction ( $95 \%$ cis by GC), $28 \mathrm{mg}(23 \%)$ of a yellow oil as the second fraction ( $11 \% \mathrm{cis}, 88 \%$ trans by GC), and $29 \mathrm{mg}(24 \%)$ of a yellow oil as the third fraction ( $90 \%$ trans by GC). cis-6d: $[\alpha]^{20} \mathrm{D}$ $-87.0^{\circ}$ (c 1.00; $\mathrm{CHCl}_{3}$ ); ${ }^{1} \mathrm{H}-\mathrm{NMR}$ (200 $\mathrm{MHz}, \mathrm{CDCl}_{3}$ ) 87.17 (dd, $J=7.5,1.5 \mathrm{~Hz} 1 \mathrm{H}, \mathrm{H}-8$ ), 6.99 (ddd, $J=7.9,7.5,1.5 \mathrm{~Hz}, 1 \mathrm{H}$, $\mathrm{H}-6$ ), 6.63 (dt, $J=7.5,1.3 \mathrm{~Hz}, 1 \mathrm{H}, \mathrm{H}-7$ ), 6.46 (dd, $J=7.9,1.3$ $\mathrm{Hz}, 1 \mathrm{H}, \mathrm{H}-5), 3.87$ (m, $J=2.9 \mathrm{~Hz}, 1 \mathrm{H}, \mathrm{H}-4 \mathrm{a}), 3.60$ (s, broad, 1 $\mathrm{H}, \mathrm{NH}$ ), 1.83-1.60 (m, $5 \mathrm{H}, \mathrm{H}-3, \mathrm{H}-2 \mathrm{eq}, \mathrm{H}-4 \mathrm{eq}, \mathrm{H}-1 \mathrm{eq}, \mathrm{H}-9 \mathrm{a}$ ), 1.37 (s, 3 H, H-12), 1.27 (s, 3 H, H-13), 1.33-1.12 (m, 3 H, H-1ax, H-4ax, H-2ax), 0.94 (d, $J=6.3 \mathrm{~Hz}, 3 \mathrm{H}, \mathrm{H}-11$ ); ${ }^{13} \mathrm{C}-\mathrm{NMR}$ (50 $\left.\mathrm{MHz} \mathrm{CDCl}_{3}\right) \delta 143.0,128.2,126.4,126.1,116.1,112.8,46.7,44.5$, 41.1, 35.5, 34.7, 34.1, 26.1, 25.4, 22.9, 22.2; IR (film) 3400, 1606, $1493,1302,742 \mathrm{~cm}^{-1}$; HRMS calcd for $\mathrm{C}_{16} \mathrm{H}_{23} \mathrm{~N} 229.1830$, found 229.1836. Anal. Calcd for $\mathrm{C}_{16} \mathrm{H}_{23} \mathrm{~N}$ : C, 83.78; $\mathrm{H}, 10.11 ; \mathrm{N}, 6.11$. Found: C, 83.97; H, 10.17; N, 6.62. trans-6d: $[\alpha]^{20}{ }_{D}+111.0^{\circ}(c$ $\left.1.00 ; \mathrm{CHCl}_{3}\right) ;{ }^{1} \mathrm{H}-\mathrm{NMR}\left(200 \mathrm{MHz}, \mathrm{CDCl}_{3}\right) \delta 7.31$ (dd, $J=7.7,1.5$ 
$\mathrm{Hz} 1 \mathrm{H}, \mathrm{H}-8$ ), 7.04 (ddd, $J=7.9,7.7,1.5 \mathrm{~Hz}, 1 \mathrm{H}, \mathrm{H}-6$ ), 6.72 (“ddd", $J=7.7,1.3 \mathrm{~Hz}, 1 \mathrm{H}, \mathrm{H}-7$ ), 6.51 ("dd", $J=7.9,1.3 \mathrm{~Hz}$, $1 \mathrm{H}, \mathrm{H}-5$ ), 3.75 (s, broad, $1 \mathrm{H}, \mathrm{NH}$ ), 3.15 (ddd, $J=10.5,10.2,4.0$ $\mathrm{Hz}, 1 \mathrm{H}, \mathrm{H}-4 \mathrm{a}$ ), 2.01-1.62 (m, $6 \mathrm{H}, \mathrm{H}-3, \mathrm{H}-2 \mathrm{eq}, \mathrm{H}-4 \mathrm{eq}, \mathrm{H}-1, \mathrm{H}-9 \mathrm{a}$ ), 1.42 (s, $3 \mathrm{H}, \mathrm{H}-13), 1.21$ (s, 3 H, H-12), 1.42-1.25 (m, $2 \mathrm{H}, \mathrm{H}-4 \mathrm{ax}$, $\mathrm{H}-2 \mathrm{ax}$ ), 1.05 (d, $J=6.5 \mathrm{~Hz}, 3 \mathrm{H}, \mathrm{H}-11$ ); ${ }^{13} \mathrm{C}-\mathrm{NMR}$ ( $50 \mathrm{MHz}$, $\left.\mathrm{CDCl}_{3}\right) \delta 143.0,131.1,126.4(2 \times \mathrm{C}), 116.7,113.6,50.5,47.0,43.3$, $35.1,34.8,30.8,27.0,26.6,24.6,22.2$; IR (film) 3397, 1606, 1498, $1318,743 \mathrm{~cm}^{-1}$; MS (EI) $\mathrm{m} / z 229$ (M, 25), 214 (35), 187 (13), 172 (23), $158(29), 97$ (34), 55 (100); HRMS calcd for $\mathrm{C}_{16} \mathrm{H}_{23} \mathrm{~N} 229.1830$, found 229.1827 .

5,9,9-Trimethyloctahydroacridine (6e). Flash chromatography yielded $18 \mathrm{mg}$ ( $16 \%$ ) of a colorless oil as the first fraction ( $93 \%$ cis by GC) and $16 \mathrm{mg}(14 \%)$ of a yellow oil as the second fraction ( $78 \%$ trans by GC). cis-6e: ${ }^{1} \mathrm{H}-\mathrm{NMR}\left(200 \mathrm{MHz}, \mathrm{CDCl}_{3}\right.$ ) $\delta 7.05$ (d, $J=7.4 \mathrm{~Hz}, 1 \mathrm{H}, \mathrm{H}-8), 6.89$ ("d", $J=7.4 \mathrm{~Hz}, 1 \mathrm{H}, \mathrm{H}-6$ ), 6.56 (t, $J=7.4 \mathrm{~Hz}, 1 \mathrm{H}, \mathrm{H}-7$ ), 3.87 (m, $J=1.9 \mathrm{~Hz}, 1 \mathrm{H}, \mathrm{H}-4 \mathrm{a}$ ), 3.34 (s, broad, $1 \mathrm{H}, \mathrm{NH}), 2.11$ (s, $3 \mathrm{H}, \mathrm{H}-13), 1.67-1.10(\mathrm{~m}, 7 \mathrm{H}$, H-3, H-2eq, H-4eq, H-1, H-9a), 1.33 (s, $3 \mathrm{H}, \mathrm{H}-12$ ), 1.23 (s, $3 \mathrm{H}$, $\mathrm{H}-11$ ), 1.33-1.12 (m, $2 \mathrm{H}, \mathrm{H}-4 \mathrm{ax}, \mathrm{H}-2 \mathrm{ax}$ ), $1.10-0.85$ (m, $2 \mathrm{H}, \mathrm{H}-4 \mathrm{eq}$, H-2eq); ${ }^{13} \mathrm{C}-\mathrm{NMR}\left(50 \mathrm{MHz}, \mathrm{CDCl}_{3}\right) \delta 140.9,127.6,127.3,124.0$, 119.4, 115.5, 46.1, 44.5, 35.8, 33.9, 32.5, 26.3, 25.9, 22.8, 19.6, 17.5; IR (KBr) 3436, 1598, 1478, 1308, $740 \mathrm{~cm}^{-1}$. Anal. Calcd for $\mathrm{C}_{16} \mathrm{H}_{23} \mathrm{~N}: \mathrm{C}, 83.78 ; \mathrm{H}, 10.11 ; \mathrm{N}, 6.11$. Found: $\mathrm{C}, 83.69 ; \mathrm{H}, 10.02$; $\mathrm{N}, 6.03$. trans-6e: ${ }^{1} \mathrm{H}-\mathrm{NMR}\left(200 \mathrm{MHz}, \mathrm{CDCl}_{3}\right) \delta 7.18(\mathrm{~d}, J=$ $7.5 \mathrm{~Hz}, 1 \mathrm{H}, \mathrm{H}-8$ ), 6.91 (dd, $J=7.5,0.8 \mathrm{~Hz}, 1 \mathrm{H}, \mathrm{H}-6$ ), 6.56 (t, $J=7.6 \mathrm{~Hz}, 1 \mathrm{H}, \mathrm{H}-7$ ), 3.53 (s, broad, $1 \mathrm{H}, \mathrm{NH}$ ), 3.10 (ddd, $J=$ $10.3,10.0,4.2 \mathrm{~Hz}, 1 \mathrm{H}, \mathrm{H}-4 \mathrm{a}), 2.20-1.15$ (m, $9 \mathrm{H}, \mathrm{H}-2, \mathrm{H}-1, \mathrm{H}-3$, $\mathrm{H}-4, \mathrm{H}-9 \mathrm{a}), 2.13$ (s, $3 \mathrm{H}, \mathrm{H}-13$ ), 1.36 (s, $3 \mathrm{H}, \mathrm{H}-11), 1.16$ (s, $3 \mathrm{H}$, H-12); ${ }^{13} \mathrm{C}-\mathrm{NMR}\left(50 \mathrm{MHz} \mathrm{CDCl}_{3}\right) \delta 140.8,130.5,127.6,124.3$, $119.9,116.0,50.9,47.1,35.0,27.9,27.0,26.6,26.4,25.0,24.6,17.4$; IR (KBr) $3420,1598,1478,1302,739 \mathrm{~cm}^{-1}$; MS (EI) $\mathrm{m} / z 229$ (M, 14), 214 (25), 163 (16), 153 (18), 95 (39), 55 (100); HRMS calcd for $\mathrm{C}_{16} \mathrm{H}_{23} \mathrm{~N} 229.1830$, found 229.1827 .

9,9-Dimethyloctahydroacridine (6f). Flash chromatography yielded $8 \mathrm{mg}(7 \%)$ of a yellow oil as the first fraction $(98 \%$ cis by GC) and $57 \mathrm{mg}(53 \%)$ of a yellow oil as the second fraction (75\% trans by GC). cis-6f: ${ }^{1} \mathrm{H}-\mathrm{NMR}\left(200 \mathrm{MHz}, \mathrm{CDCl}_{3}\right) \delta 7.12$ (dd, $J=7.5,1.5 \mathrm{~Hz}, 1 \mathrm{H}, \mathrm{H}-8$ ), 6.96 (ddd, $J=7.9,7.5,1.5 \mathrm{~Hz}$, $1 \mathrm{H}, \mathrm{H}-6$ ), 6.60 (dt, $J=7.4,1.2 \mathrm{~Hz}, 1 \mathrm{H}, \mathrm{H}-7$ ), 6.44 (dd, $J=7.9$, $1.2 \mathrm{~Hz}, 1 \mathrm{H}, \mathrm{H}-5), 3.83(\mathrm{~m}, J=2.4 \mathrm{~Hz}, 1 \mathrm{H}, \mathrm{H}-4 \mathrm{a}), 3.53$ (s, broad, $1 \mathrm{H}, \mathrm{NH}$ ), 1.74-1.15 (m, $7 \mathrm{H}, \mathrm{H}-3, \mathrm{H}-4 \mathrm{eq}, \mathrm{H}-2 \mathrm{eq}, \mathrm{H}-1, \mathrm{H}-9 \mathrm{a}$ ), 1.32 (s, $3 \mathrm{H}, \mathrm{H}-12$ ), 1.21 (s, $3 \mathrm{H}, \mathrm{H}-11), 1.15-0.85$ (m, $2 \mathrm{H}, \mathrm{H}-4 \mathrm{ax}$, H-2ax); ${ }^{13} \mathrm{C}-\mathrm{NMR}\left(50 \mathrm{MHz} \mathrm{CDCl}_{3}\right.$ ) $\delta 143.1,128.1,126.5,126.1$, $116.2,112.9,46.1,44.7,35.7,34.0,32.4,26.0,25.8,22.7,19.6$; IR (film) $3400,1606,1493,1303,742 \mathrm{~cm}^{-1}$; HRMS calcd for $\mathrm{C}_{15} \mathrm{H}_{21} \mathrm{~N}$ 215.1674, found 215.1674. trans-6f: ${ }^{1} \mathrm{H}-\mathrm{NMR}\left(200 \mathrm{MHz}, \mathrm{CDCl}_{3}\right)$ 8 7.20-7.12 (m, $2 \mathrm{H}, \mathrm{H}-8, \mathrm{H}-6), 6.67-6.51$ (m, $2 \mathrm{H}, \mathrm{H}-7, \mathrm{H}-5), 3.92$ (s, broad, $1 \mathrm{H}, \mathrm{NH}$ ), 3.15 (ddd, $J=10.5,10.2,4.0 \mathrm{~Hz}, 1 \mathrm{H}, \mathrm{H}-4 \mathrm{a}$ ), 2.11-1.45 (m, 9 H, H-3, H-4, H-2, H-1, H-9a), 1.68 (s, 3 H, H-11), 1.45 (s, $3 \mathrm{H}, \mathrm{H}-12) ;{ }^{13} \mathrm{C}-\mathrm{NMR}\left(50 \mathrm{MHz}, \mathrm{CDCl}_{3}\right) \delta 143.3,131.0$, $126.4,126.3,116.7,113.4,50.8,47.3,35.7,27.6,25.6(2 \times C), 24.8$, 24.7, 24.4; IR (film) $3397,1606,1498,1319,743 \mathrm{~cm}^{-1}$; MS (EI) $\mathrm{m} / z$ $215(\mathrm{M}, 35), 200(100), 182(15), 157$ (24), 97 (32), 91 (28), 55 (85); HRMS calcd for $\mathrm{C}_{15} \mathrm{H}_{21} \mathrm{~N} 215.1674$, found 215.1671.

Acknowledgment. Generous financial support by the Alfried Krupp von Bohlen und Halbach-Stiftung is gratefully acknowledged. S.L. thanks the Wissenschaftsministerium Nordrhein-Westfalen for a Lise Meitner fellowship. We wish to thank Dr. Christian Sarter for his help with NMR experiments.

Supplementary Material Available: Portions of the 360$\mathrm{MHz}$ NOESY spectra of trans-6c and cis-6c and cross sections through selected ${ }^{13} \mathrm{C}$ chemical shifts of the $90.5-\mathrm{MHz},{ }^{13} \mathrm{C}, 1 \mathrm{H}$ shiftcorrelated 2D-NMR of cis-6c (4 pages). This material is contained in libraries on microfiche, immediately follows this article in the microfilm version of the journal, and can be ordered from the ACS; see any current masthead page for ordering information. 